\title{
Biocontrol strategies to reduce the impact of Septoria tritici blotch in
}

\author{
wheat \\ ${ }^{*}$ Cristina Cordo ${ }^{1,2}$; Rodrigo Altamirano3; María Rosa Simónn',4; Marina Stoccoㄹ; Gladys \\ Lampugnani ${ }^{5}$; Cecilia Abramoff ${ }^{5}$ Natalia Kripelz ${ }^{1,2}$; Cecilia Mónaco ${ }^{1}$ \\ ${ }^{1}$ Centro de Investigaciones de Fitopatología (CIDEFI), Fac. Ciencias Agrarias y Ftales- UNLP, Argentina; \\ ${ }^{2}$ Comisión de Investigaciones Científicas, Buenos Aires (CICBA), Argentina; ${ }^{3}$ Curso de Bioestadística, Fac. \\ Ciencias Agrarias y Ftales- UNLP, Argentina; ${ }^{4}$ Curso de Cerealicultura, Fac. Ciencias Agrarias y Ftales- UNLP, \\ Argentina; ${ }^{5}$ Curso de Terapéutica Vegetal, Fac. Ciencias Agrarias y Ftales- UNLP, Argentina \\ *cristcordo@gmail.com
}

Cordo Cristina; Rodrigo Altamirano; María Rosa Simón; Marina Stocco; Gladys Lampugnani; Cecilia Abramoff; Natalia Kripelz; Cecilia Mónaco (2020). Biocontrol strategies to reduce the impact of Septoria tritici blotch in wheat. Rev. Fac. Agron. Vol 119 (2): 1-10. https://doi.org/10.24215/16699513e060

Trichoderma strains are used as biofungicides for some plant diseases. The aim of this research was to evaluate the effectiveness of Trichoderma harzianum isolates, applied alone and in combination with fungicides, to control Zymoseptoria tritici, the causal agent of Septoria tritici blotch of wheat, and their impact on wheat yield and its components. To this end, field experiments were performed in 2010 and 2011 and 10 different treatments were applied. The disease severity was assessed by visual estimation of the leaf area affected by $Z$. tritici at the first node, anthesis and early dough growth stages. The best results for reducing the area under the disease progress curve (AUDPC) were "coated seed only with T. harzianum" and "coated seed plus two foliar application of $T$. harzianum". Regarding the increase in yield gain and the improvement of yield components, the fungicide treatment applied at seedling, and tillering in 2011 provided significant increase. Respect the treatments with the application of $T$. harzianum the best was only one application as coated seed of the biocontroler alone showing yield responses similar to the ones obtained with the fungicide treatments. We recommended the coated seed alone because the protective effect lasts until the early dough stage of ripening. This application produced a comparable yield to that obtained with three applications of $T$. harzianum at different phenological stages of wheat with as well as with more than one application of commercial fungicide. We found a strong relationship between the number of kernels per spike and the wheat yield in 2011 as a consequence of the best environmental conditions for the disease's occurrence. Contrary, it was shown a non-significant association between thousand kernel weight (TKW) and the wheat yield.

Key words: biological control; septoria tritici blotch; Trichoderma harzianum; wheat yield; fungicide

Cordo Cristina; Rodrigo Altamirano; María Rosa Simón; Marina Stocco; Gladys Lampugnani; Cecilia Abramoff; Natalia Kripelz; Cecilia Mónaco (2020). Estrategias de control para reducir el impacto de la mancha de la hoja del trigo. Rev. Fac. Agron. Vol 119 (2): 1-10. https://doi.org/10.24215/16699513e060

Las cepas de Trichoderma se usan como biofungicidas para el control de algunas enfermedades de las plantas. El objetivo de esta investigación fue evaluar la efectividad de dos cepas de Trichoderma harzianum, aplicadas solas y en combinación con fungicidas, para controlar Zymoseptoria tritici, el agente causal de la mancha de la hoja del trigo, y su impacto en el rendimiento del trigo y sus componentes. Con este fin, se realizaron experimentos de campo en 2010 y 2011 y se aplicaron 10 tratamientos diferentes. La severidad de la enfermedad se evaluó mediante la estimación visual del área de la hoja afectada por $Z$. tritici en el estadio de primer nudo, en antesis y en grano pastoso. Los mejores resultados para la reducción del área bajo la curva de progreso de la enfermedad (ABCPE) fueron "semillas recubiertas solamente con $T$. harzianum" y "semillas recubiertas más dos aplicaciones foliares de T. harzianum". Para un mayor rendimiento y la mejora de los componentes de rendimiento, el mejor tratamiento fue: solo una aplicación de T. harzianum (como "semillas recubiertas"). Recomendamos este tratamiento porque el efecto protector dura hasta la etapa temprana de maduración del grano. Esta aplicación produjo un rendimiento comparable al obtenido con tres aplicaciones de $T$. harzianum en diferentes estados fenológicos del trigo y, además de con más de una aplicación de fungicida comercial. Existió una relación significativa entre el número de granos por espiga y el rendimiento de trigo en 2011, como consecuencia de las mejores condiciones ambientales para el desarrollo de la enfermedad. Por el contrario, se mostró una asociación no significativa con el peso de mil granos.

Palabras clave: control biológico; septoria tritici blotch; Trichoderma harzianum; rendimiento del trigo; fungicidas

https://revistas.unlp.edu.ar/revagro

Recibido: 26/03/2020

Aceptado: $14 / 07 / 2020$

Disponible on line: $07 / 12 / 2020$

ISSN 0041-8676 - ISSN (on line) 1669-9513, Facultad de Ciencias Agrarias y Forestales, UNLP, Argentina. 


\section{INTRODUCTION}

"Septoria tritici blotch" (STB), caused by Zymoseptoria tritici (Desm.) Quaedvlig \& Crous, is an important disease causing significant yield losses in many wheat-producing areas of the world (Thompson \& Gaunt,1986; Rodrigo et al., 2015). Early infections can reduce the number of grains per spike, whereas late infections can reduce the thousand kernel weight (Simón et al., 2002). In Argentina, yield losses of $20-50 \%$ were reported (Annone et al., 1991; 1993), whereas Simón et al. (1996) reported a reduction in thousand kernel weight of infected plants of 3-13\%. In Argentina, the most frequent genetic background of wheat cultivars varies from moderately susceptible to moderately resistant to STB (Simón et al., 2013). Thus, a frequent approach to control STB is breeding for resistance (Simón et al., 2016), but in the wheat growing area, STB is controlled mainly by the use of fungicides.

The fungicides usually used consist of mixtures of triazoles (which inhibit ergosterol biosynthesis) and strobilurins (which inhibit mitochondrial respiration) in the same formula because the latter could lead to substantial increases in yield in the order of $10-20 \%$ above that produced by conventional fungicides. These increases would be associated with the maintenance of canopy photosynthesis during the grain filling period but also with the prolongation of the duration of the green leaf area (Gooding et al., 2000).

In an effort to minimize the use of chemicals, several researchers have investigated the use of antagonistic microbes, both alone and as supplements. In Argentina, for example, the biocontrol of $Z$. tritici via foliar application on wheat leaves has been well documented (Perelló et al., 1997; Perelló et al., 2006; Cordo et al., 2007; Perelló et al., 2008; Stocco et al., 2012).

Members of the fungal genus Trichoderma are able to act as biocontrol agents (Harman, 2006; Harman et al., 2004; Perelló et al., 2008). They protect plants against the attack of plant pathogens by competing for nutrients and inhibiting or killing plant pathogenic fungi and oomycetes through the production of antibiotics and/or hydrolytic enzymes. The contribution of Trichoderma spp. to plant growth and defense mechanisms were reviewed (Hermosa et al., 2013) by describing the complex plant defense signaling network, that allows the recognition of this fungus as non-hostile microbes.

In Argentina, some products based on Trichoderma are manufactured under trademarks as Rizoderma ${ }^{\circledR}$ by Rizobacter and Biagro TL® by Biagro S.A. and used as fertilizers or growth promoters. Moreover, many Trichoderma strains are included as active biofungicide matter in registered biological control substances or commercial formulations against plant pathogenic fungi (Monte, 2001). Among them, Trichoderma harzianum Rifai is a soil-borne free-living fungus that colonizes the roots of many plants as an opportunistic, non-virulent plant symbiont (Harman et al., 2001), which has been used in biotechnological applications both as a biofungicide and as a growth promoter, providing important benefits to agriculture under field conditions (Lorito et al., 2004). So far, all published works on the biocontrol of $Z$. tritici by $T$. harzianum in wheat have studied only the reduction of disease severity. Thus, to gain further insights into the biocontrol of $Z$. tritici by $T$. harzianum, the aim of this study was to evaluate the effect of $T$. harzianum, applied alone and in combination with fungicides, on grain yield and its components in wheat plants affected by $Z$. tritici.

\section{MATERIALS AND METHODS}

\section{Isolation of $Z$. tritici strains from infected leaves}

Two virulent strains of $Z$. tritici (FALP9J008 and FALPLA008), from the cities of 9 de Julio and Plá (Buenos Aires province, Argentina) respectively, were obtained from wheat leaves with typical lesions with pycnidia. Each strain was grown on potato-dextrose agar (PDA; Difco Laboratories) at $20 \pm 2^{\circ} \mathrm{C}$. Pycnidia developed spores that were released under the form of a cirrhus. One single spore was isolated and cultured on water agar. On day 6 after isolation the small colony developed from the single spore was replicated in Petri dishes onto modified malt agar (30 g malt extract, $5 \mathrm{~g}$ mycological peptone, $2 \mathrm{~g}$ yeast extract and $1000 \mathrm{~mL}$ distilled water) for sporulation. On day 9, the mucous mass of conidia for each strain was harvested by flooding the plate with $5 \mathrm{~mL}$ of sterile distilled water and dislodging the conidia with a bent glass rod. The resulting suspension was filtered through cheesecloth and the concentration of the conidial suspension was adjusted to $5 \times 10^{6}$ sporesmL $^{-1}$ as were reported by Cordo et al, (2007) and Perello et al. (2008). The inocula from the two strains were mixed at equal volumes to obtain the inoculum volume used in the experiment adjusted for each growth stage. The resulting suspension was mixed with $50 \mu^{-1}(0.05 \% \mathrm{v} / \mathrm{v})$ of Tween 20 in aqueous solution as a surfactant.

\section{Identification of Trichoderma species}

Two isolates of Trichoderma spp. (FALH5cc and FALH118c, isolated from soil samples of cultivated wheat and from soil samples of cultivated tomatoes, respectively) were chosen from the collection of Centro de Investigaciones de Fitopatología of the Facultad de Ciencias Agrarias y Forestales of the Universidad Nacional de La Plata, Argentina. These strains have been previously evaluated in other experiments with different cultures in INBIOTEC-CONICET-FIBA (Cordo et al., 2007; Mónaco et al., 2008).

The DNA of each Trichoderma strain was obtained following a modified version of the cetyltrimethylammonium bromide (CTAB) method (Murray \& Thompson, 1980). The internal transcribed spacers (ITS) of the ribosomal DNA (RDNA) region from each Trichoderma isolate were PCR amplified. The PCR products were separated by electrophoresis in a gel containing $1 \%$ agarose (Genbiotech SRL, Buenos Aires, Argentina) in 1x TAE buffer (40 mm tris-hcl, $\mathrm{pH} 8$, and 2 $\mathrm{mm}$ EDTA). Gels were run for $1 \mathrm{~h}$ at $120 \mathrm{v}$, stained with gel red (Biotium, Hayward, USA) and photographed with a fotodyne system (Hartland,Wi, USA). The PCR amplification products were purified and sequenced by Macrogen (Korea), using the primer ITS4.

Each sequence was uploaded to Genbank and compared with those of known origin by using the blast search program (Altschul et al., 1997). Based on its sequences the strains FALH5CC and FALH118c (Cordo et al., 2007; Mónaco et al., 2008) were PCR amplified with specific primers and sequenced. Both ITS 
sequences were in the European molecular biology laboratory (EMBL) database (Miyazaki et al. 2009). The strain FALH5cc, (accession number LN 869401) and the strain FALH118c, (accession number LN 869400), had $99 \%$ of similarity with a strain (Accession $\mathrm{N}^{\circ} \mathrm{T} 6776$ ) of $T$. harzianum, and both strains had $99 \%$ of similarity with a strain of Hypocrea lixii (Cib t136), that is the teleomorph stage of them.

\section{Production of Trichoderma sp. Inoculum}

The two $T$. harzianum isolates mentioned above were used for inoculum production. The isolates were cultured on PDA in Erlenmeyer flasks and incubated for 7-15 days at $20 \pm 2^{\circ} \mathrm{C}$ in a growth chamber under a photoperiod of $12 \mathrm{~h}$ with fluorescent plus near ultraviolet lights. The conidia of each isolate were harvested by flooding the cultures with sterile distilled water and then rubbing the culture surfaces with a sterile glass rod. After filtering the suspensions through two layers of cheesecloth, the concentrations of propagules in the suspensions were standardized with the aid of a hemocytometer to $1 \times 10^{8}$ conidia per $\mathrm{mL}$ for each Trichoderma isolate tested. Suspensions were amended with one drop of Tween 20 at $0.05 \%(\mathrm{v} / \mathrm{v})$ and shaking with a magnetic stirrer bar until a homogeneous suspension was obtained. Wheat seeds $(50 \mathrm{~g})$ of the cultivar Buck 55CL2 (moderately susceptible) (reported by Buck catalog 2010) were added to $100 \mathrm{~mL}$ of the water agar-fungal biomass mixture to coat the seeds. Seeds were dried overnight at room temperature and stored in hermetically closed glass flasks at $5^{\circ} \mathrm{C}$ in a refrigerator for $24-48 \mathrm{~h}$ until used.

\section{Field experiment}

The fungicide used for the combined treatment was the formulated product Amistar Xtra® $(20 \% \mathrm{w} / \mathrm{v}$ of Azoxystrobin and $8 \% \mathrm{w} / \mathrm{v}$ of Cyproconazole) at a rate of $300 \mathrm{~cm}^{3} \mathrm{ha}^{-1}$ in a volume of $150 \mathrm{~L}$ of water. To evaluate the sensitivity of Trichoderma to this fungicide, it was filtered with a Millipore membrane of $0.45 \mu \mathrm{m}$ andadded to the PDA medium at $50^{\circ} \mathrm{C}$ after autoclaving.

Aliquots of $19000 \mathrm{ppm}$ (Leroux et al., 2007) of the formulated product were incorporated on each PDA plate. One disc of $6 \mathrm{~mm}$ in diameter of each isolate of $T$. harzianum coming from a 6-day-old culture on PDA was placed in the center of the plate on the surface of the culture medium. Ten replicates of each $T$. harzianum isolate used for each condition (with and without fungicide) were performed. The plates were incubated at $22^{\circ} \mathrm{C}$ and $12 \mathrm{~h}$ of light/dark cycles and observed after 7 day of incubation. The colony size was measured with a caliber and was expressed in $\mathrm{cm}$. Fungicide tolerance for each isolated was determined by calculating the relative colony size with and without the fungicide.

Evaluation of $T$. harzianum, applied alone and in combination with the fungicide, on STB severity

Field experiments were carried out at the Estación Experimental J. Hirschhorn, Facultad de Ciencias Agrarias y Forestales, Universidad Nacional de La Plata, Buenos Aires, Argentina ( $34^{\circ} 52^{\prime} \mathrm{S}, 57^{\circ} 58^{\prime} \mathrm{W}$ ) for two years (2010-2011). The soil was a Phaeozem luvico (USDA -FAO 1975) with a silt loam texture and slight internal drainage deficiency. The analysis of the soil samples (top $0.20 \mathrm{~m}$ ) indicated the following values by weight: organic matter $3 \%, \mathrm{~N}=0.17 \%, \mathrm{P}=7 \mathrm{mg} \mathrm{kg}^{-1}$, and $\mathrm{pH}=5.9$.

Weather conditions (mean monthly values of temperature $\left({ }^{\circ} \mathrm{C}\right)$, precipitation $(\mathrm{mm})$, relative humidity $(\mathrm{RH})$, and global radiation $\left(\mathrm{W} \mathrm{m}^{-2} \mathrm{~d}^{-1}\right)$ were recorded at a meteorological station situated $100 \mathrm{~m}$ from the experiments.

Plots consisted of $4.2 \mathrm{~m}^{2}$ ( $1.4 \mathrm{~m}$ wide by $3 \mathrm{~m}$ long). The total area of each replication, which consisted of 21 plots, was $84.2 \mathrm{~m}^{2}$. The entire experiment was fertilized with $\mathrm{N}$ (as urea $\left.100 \mathrm{~kg} \mathrm{ha}^{-1}\right)$ and $\mathrm{P}\left(50 \mathrm{~kg} \mathrm{PO}_{4}\left(\mathrm{NH}_{4}\right)_{2} \mathrm{ha}^{-1}\right)$ at the time of sowing.

The experimental design was a complete randomized block with 10 treatments (T1-T10) and the control (Table 1) and three replications with a row-to-row distance of 15 $\mathrm{cm}$ in both years. The bread wheat (Triticum aestivum L.) cultivar Buck 55 CL2 was sown at a sowing density of 320 and 300 plants $\mathrm{m}^{-2}$ for 2010 and 2011 , respectively, depending of the date of sown.

Two T. harzianum isolates were applied as follows: i) as seed coating $\left(1 \times 10^{8}\right.$ conidia $\mathrm{mL}^{-1}$ of each $T$. harzianum isolate (Perello et al., 2008), ii) as spraying the spore suspension alone $\left(1 \times 10^{8}\right.$ conidia $\mathrm{mL}^{-1}$ of each $T$. harzianum isolate (Perelló et al., 2008) or iii) as spraying the spore suspension combined with half the doses of the fungicide Amistar Xtra $\AA$, equivalent to $300 \mathrm{~cm}^{3} \mathrm{ha}^{-1}$. The goal of the fungicide applications was to compare the efficacy of the $T$. harzianum treatment with that of the fungicide. The fungal inoculum and fungicide were applied three times between August and October at the seedling (GS12), (Zadoks et al., 1974), tillering (GS31) and heading growth stages (GS54). When the fungicide was applied alone, it was sprayed at a rate of $600 \mathrm{~cm}^{3}$ in $150 \mathrm{~L}$ of water per ha ${ }^{-1}$ at each growth stage for the same plants and lastly at heading as the only moment of application. Oat strips were sown between plots to avoid the spread of the inoculum between treatments. Oat strips were also sown between replications.

Strategies used: $=\mathrm{T} 1, \mathrm{~T} 2$ and $\mathrm{T} 3$ biocontrol only; T4 to T6: biocontrol and fungicide combined; T7 to T10: fungicide only (negative control).

To ensure the vertical dispersion of the disease, the pathogen was inoculated three times. Both for the inoculation with $Z$. tritici and for the application of $T$. harzianum strains, the final volume for each growth stage was changed according to the size of plants. The final volume at seedling was $1.5 \mathrm{~L}$, at tillering $2.75 \mathrm{~L}$, and at heading $5 \mathrm{~L}$ for each treatment. Plants were sprayed with the inoculum suspension until runoff.

After inoculations, plants were kept moist by spraying water several times a day (every $3 \mathrm{~h}$ from 9 am to 18 pm), for 3 days with a sprayer for applying pesticides. The pathogen was inoculated in all the treatments, including the controls.

In both years, the disease severity was assessed by visual estimation of the percentage of the leaf area affected by $Z$. tritici on twelve plants from each plot at the following growth stages: on the upper two leaves from the second and sixth rows when each cultivar reached the first node (GS31), anthesis (GS62) and early dough (GS82). The area under the disease progress curve (AUDPC) for each treatment was calculated to summarize the progress of the disease (Shanner \& Finney, 1977). 
Table 1: Treatments applied on the wheat cultivar Buck 55CL2 to control STB either with Trichoderma harzianum strains alone or combining $T$. harzianum and a fungicide. The pathogen Z. tritici was artificially inoculated in all the treatments.

\begin{tabular}{|c|c|c|}
\hline Treatments & Growth Stages & \\
\hline Positive Control & GS12, 31, 54 & wheat plants inoculated only with $Z$. tritici \\
\hline $\mathrm{T} 1^{*}$ & GS12 & wheat seeds coated with strains of $T$. harzianum \\
\hline T2 & GS12, 31 & $\begin{array}{l}\text { wheat seeds coated with strains of } T \text {. harzianum }+T \text {. harzianum } \\
\text { spraying onto the leaves at tillering }\end{array}$ \\
\hline T3 & GS12, 31,54 & $\begin{array}{l}\text { wheat seeds coated with strains of } T \text {. harzianum }+T \text {. harzianum } \\
\text { spraying onto the leaves at tillering and heading. } \\
\text { wheat seeds coated with } T \text {. harzianum strains }+ \text { foliar fungicide (half }\end{array}$ \\
\hline T4 & GS12 & $\begin{array}{l}\text { commercial dose) at seedling }+T \text {. harzianum spraying onto the } \\
\text { leaves. } \\
\text { wheat seeds coated with } T \text {. harzianum strains }+ \text { foliar fungicide (half }\end{array}$ \\
\hline T5 & GS12, 31 & $\begin{array}{l}\text { commercial dose) at tillering }+T \text {. harzianum spraying onto the } \\
\text { leaves. }\end{array}$ \\
\hline T6 & GS12, 31, 54 & $\begin{array}{l}\text { wheat seeds coated with } T \text {. harzianum strains }+ \text { foliar fungicide (half } \\
\text { commercial dose) at tillering and heading + Trichoderma spraying } \\
\text { onto the leaves at tillering and heading. }\end{array}$ \\
\hline T7 & GS12 & foliar fungicide (commercial dose) at seedling. Negative control. \\
\hline T8 & GS12, 31 & $\begin{array}{l}\text { foliar fungicide (commercial dose) at seedling and tillering. Negative } \\
\text { control. }\end{array}$ \\
\hline T9 & GS12, 31, 54 & $\begin{array}{l}\text { foliar fungicide (commercial dose) at seedling, tillering and heading. } \\
\text { Negative control. }\end{array}$ \\
\hline T10 & GS54 & foliar fungicide (commercial dose) at heading. Negative control. \\
\hline
\end{tabular}

\section{Evaluation of yield components}

The yield components calculated for each plot were: number of spikes per square meter $\left(\mathrm{SPM}^{-2}\right)$, number of kernels per spike (KPS), and thousand kernel weight (TKW). To this end, three 1-m sections from the three central rows of each plot were hand-harvested and threshed and the number of spikes per square meter counted. KPS was then determined in 30 spikes, by threshing the heads and counting the kernels. The kernels counted in the 30 spikes were weighed to calculate TKW. Grain yield (in $\mathrm{kg} \mathrm{ha}^{-1}$ ) was calculated using the yield components.

The percentage of yield gain due to the effect of the different treatments with $T$. harzianum respect to the control (wheat inoculated only with $Z$. triticl) was calculated as a comparison between the yield in the control (i.e. in the absence of fungicide application but in presence of disease) and the yield obtained in each of the treatments (T1-T10). The yield gain in the control was set as 0 .

\section{Statistical analysis}

To assess the effect of the different treatments on the evolution on the AUDPC values and on yield and yield components, an ANOVA was performed for data of both years separately, according to the variables year, treatments, and T. harzianum isolates. As there was not different behavior between the Trichoderma strains used in this assay, the values of the AUDPC and yield for both strains were averaged. Tukey's test $(P<0.05)$ was applied for the variables and interactions that differed significantly.

Linear regression analysis was used to describe the relationship between AUDPC values and grain yield of wheat plants affected by STB. The equation was $Y=a X$ $+b$, where $Y$ is the predicted yield, $b$ is the expected yield in the absence of disease (both expressed in $\mathrm{kg} \mathrm{ha}^{-1}$ ), $X$ corresponds to the disease score, and $\mathrm{a}$ is the regression coefficient that expresses the linear yield loss in $\mathrm{kg} \mathrm{ha}^{-1}$.

\section{RESULTS}

Effect of T. harzianum, applied alone and in combination with the fungicide, on STB severity In vitro test revealed that none of the $T$. harzianum isolates were affected by the fungicide dose used in the combined treatment. The mycelia of both biocontrol agents reached $9 \mathrm{~cm}$ of mean diameter at 7 days of growth.

In 2010, the average temperature for the entire period after inoculation was $15.7^{\circ} \mathrm{C}$, the total rainfall was 257.2 $\mathrm{mm}$, the average $\mathrm{RH}$ was $71 \%$, and the average radiation was $4347 \mathrm{~W} \mathrm{~m}^{-2} \mathrm{~d}^{-1}$, whereas in 2011, the average temperature was $15.9^{\circ} \mathrm{C}$, the total rainfall was $278.2 \mathrm{~mm}$, the average $\mathrm{RH}$ was $68 \%$, and the average radiation was $5852 \mathrm{~W} \mathrm{~m}^{-2} \mathrm{~d}^{-1}$.

The temperature and radiation in 2011 during August and September were higher than in 2010 (Table 2). This increase could favour the expression of tills. For this reason $\mathrm{SPM}^{-2}$ could be influenced with the increase in number of plants, leaves and the future spikes.

Because of the greater precipitations in 2011, the environmental conditions in this year could be more favorable for the development of the disease. The total rain accumulated between tillering and heading (October 4 and November 21) in 2011 was $141.2 \mathrm{~mm}$, whereas in the same period in 2010, was only $47.8 \mathrm{~mm}$. The $73 \mathrm{~mm}$ more of rainfall across 48 days could explain the better development of the Septoria tritici blotch in 2011 because 
important stages of plant differentiations (from the first node visible to boot stages) took place, increasing the final number of infected leaves.

The AUDPC values were compared with the positive control (wheat plants only inoculated with $Z$. tritici) to obtain the reduction of the severity for the effect of the treatments. The negative controls (T7, T8, T9 and T10) added results to define the effectiveness of the various $T$. harzianum treatments, comparing each T.harzianum treatment with each negative control relating them according to their plant growth stages.
There was a significant effect of the year $\times$ treatment interaction on the AUDPC variable $(F=3.081, P \leq 0.0021)$ (data not shown). Treatments T2 and T4 for 2010 and T1 and T3 for 2011, were significantly different to the positive control. Treatments T7, T8, T9 and T10 also were significantly different to the same control, although T5 and T6 were not significantly different for both years. All treatments based on fungicide application caused a significant decrease in the amount of disease (T7 to T10) with the lower values of AUDPC for T8, T9 and T10 for both years of testing (Figure 1).

Table 2. Weather variables affecting wheat in the field experiment during August-December 2010-2011 in Estación Experimental J. Hirschhorn, La Plata, Buenos Aires province, Argentina. Ref.: Mean $T^{\circ} \mathrm{C}=$ mean temperature in Celsius degrees; $S$. mean $T^{\circ} \mathrm{C}=$ soil mean temperature in Celsius degrees; Sun Radiation = in Wats .m-2; Pp = Precipitation in $\mathrm{mm} ; E T P=$ Evapotranspiration in $\mathrm{mm} ; \mathrm{RH}=$ Relative humidity in percentage (\%).

\begin{tabular}{|c|c|c|c|c|c|c|c|c|c|c|c|c|}
\hline \multirow[b]{2}{*}{ Months } & \multicolumn{2}{|c|}{ Mean $\mathbf{T}^{\circ} \mathrm{C}$} & \multicolumn{2}{|c|}{ S. mean $\mathrm{T}^{\circ} \mathrm{C}$} & \multicolumn{2}{|c|}{ Radiation } & \multicolumn{2}{|c|}{$\mathrm{Pp}$} & \multicolumn{2}{|c|}{ ETP } & \multicolumn{2}{|c|}{$\mathbf{R H}$} \\
\hline & 2010 & 2011 & 2010 & 2011 & 2010 & 2011 & 2010 & 2011 & 2010 & 2011 & 2010 & 2011 \\
\hline August & 9.8 & 9.7 & 9.5 & 10.3 & 2513 & 2260 & 26.8 & 56 & 54.1 & 50.7 & 76 & 76 \\
\hline September & 13.1 & 13.7 & 12.8 & 13.6 & 3171 & 3665 & 111 & 21.4 & 72 & 94.8 & 78 & 64 \\
\hline October & 14.8 & 15.2 & 14.7 & 17 & 4621 & 4239 & 40.4 & 60.4 & 107 & 100 & 73 & 73 \\
\hline November & 18 & 20.3 & 17.6 & 21.4 & 5302 & 5586 & 28 & 81.8 & 127 & 143 & 70 & 64 \\
\hline December & 22.6 & 20.4 & 21.6 & 21.4 & 6128 & 5852 & 51 & 58.6 & 176 & 152 & 58 & 68 \\
\hline
\end{tabular}

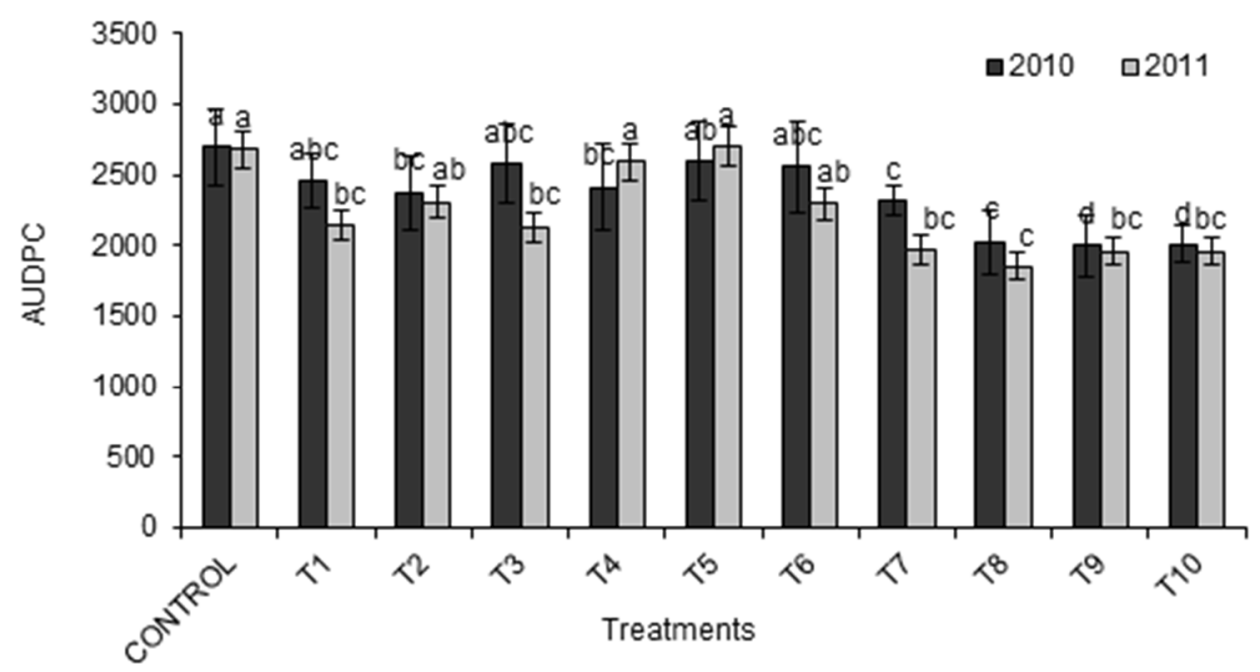

Figure 1. Means of the area under the disease progress curve (AUDPC) (two upper leaves) of the "Septoria tritici blotch" (STB) caused by Zymoseptoria tritici in 10 treatments with Trichoderma harzianum/fungicide and the positive control (CONTROL) (Table 1) for the wheat cultivar Buck 55 CL2 in field experiments carried out in 2010 and 2011. Strategies used: = T1, T2 and T3 biocontrol only; T4 to T6: biocontrol and fungicide combined; T7 to T10: fungicide only (negative control). Treatments with similar letters are not statistically different. Bars indicated standard errors of the means. 


\section{Effect of $T$. harzianum-based treatments on yield components}

The yield values obtained in 2010 and 2011 did not statistically differ from the positive control, except T9 for 2010, which included three fungicide applications. Although the yield values do not differ statistically between treatments, they are higher than those of the control for both years (Table 3).

Table 3. Means of wheat yield (kg.ha-1) in 10 treatments with Trichoderma harzianum/fungicide and the positive control (CONTROL) for the wheat cultivar Buck 55 CL2, infected by Zymoseptoria tritici in field experiments carried out in 2010 and 2011. Strategies used: = T1, T2 and T3 biocontrol only; T4 to T6: biocontrol and fungicide combined; T7 to T10: fungicide only (negative control). *treatments with similar letters are not statistically different.

\begin{tabular}{lcc}
\hline Treatments & \multicolumn{2}{c}{ Grain Yield } \\
& 2010 & Kg.ha- \\
& 2011 \\
\hline Control & $4287.8 \mathrm{ab}$ & $2987 \mathrm{a}$ \\
T1 & $5425.2 \mathrm{abc} c^{\star}$ & $4086.1 \mathrm{ab}$ \\
T2 & $5573.3 \mathrm{bc}$ & $4366.3 \mathrm{ab}$ \\
T3 & $5749.6 \mathrm{bc}$ & $4455.5 \mathrm{ab}$ \\
T4 & $5380.9 \mathrm{abc}$ & $4007.2 \mathrm{ab}$ \\
T5 & $4934.8 \mathrm{abc}$ & $4354 \mathrm{ab}$ \\
T6 & $4714.8 \mathrm{abc}$ & $4417.0 \mathrm{ab}$ \\
T7 & $4876.4 \mathrm{abc}$ & $4351.0 \mathrm{ab}$ \\
T8 & $5209.8 \mathrm{abc}$ & $5363.3 \mathrm{~b}$ \\
T9 & $5986.3 \mathrm{c}$ & $3960.3 \mathrm{ab}$ \\
T10 & $3970.7 \mathrm{a}$ & $4073.0 \mathrm{ab}$ \\
\hline
\end{tabular}

The regression analysis between the yield and AUDPC was significant only for $2010(\mathrm{~F}=4.4054 ; \mathrm{P}<0.0397)$ with a small value of $R^{2}=0.0644$. This suggests that in absence of diseases (AUDPC $=0$ ) the expected value of yield would be $7235 \mathrm{~kg} \mathrm{ha}^{-1}$. On the other hand for an increase in AUDPC of 100 units, the expected yield will decrease $804 \mathrm{~kg} \mathrm{ha}^{-1}$ (Figure 2A).

Concerning the different yield components: (Table 4) for SPM- ${ }^{2}$ significant differences were observed between the positive control and treatments T1, T2, T3, T8 and T9 in 2010 , and between the positive control and the treatment T2 in 2011. For TKW no differences were observed between the positive control and the treatments $\mathrm{T} 1$ to $\mathrm{T} 6$ having $T$. harzianum in their composition and treatments T7-T10 with only fungicide application (Table 4) except T9 which was better than the control in both years. Only for KPS in both years, the positive control (only inoculated with $Z$. tritici) differed from treatment T9 (only with fungicide application). Moreover, for KPS the best treatment without fungicide application was T3, with values similar to those observed with treatments with half doses of the fungicide (Table 3).
The Simple Regression model obtained between yield and yield components affected by $Z$. tritici showed that, in 2010, which had non-favourable conditions for STB, only SPM ${ }^{2}\left(R^{2}=0.429\right)$ was able to explain its association with yield (Figure 2B), whereas, in 2011, which had favourable conditions for STB occurrence, there was a participation of KPS $\left(R^{2}=0.264\right)$ (Figure $2 C$ ) and a non-significant association with TKW $\left(R^{2}=0.04\right)$. The best yield gains using $T$. harzianum were obtained with T3, (three applications of $T$. harzianum with $25 \%$ of gain for 2010 and $32.9 \%$ for 2011 .

Treatment T6, combining T. harzianum and half dose of foliar fungicide, resulted in yield gains of $14.3 \%$ for 2010 and $29.6 \%$ for 2011 . On the other hand, foliar applications of fungicide alone (treatments T7-T10) at different phenological stages, resulted in yield gains of $12.5 \%$ for 2010 and $31.6 \%$ for 2011 .

\section{DISCUSSION}

The use of biological agents to reduce the severity of diseases like STB is a complementary strategy within integrated pest management (Hermosa et al., 2013; Lorito et al., 2010). In the present study, the application of $T$. harzianum (two strains combined) at wheat seeds (seed coating), tillering and heading growth stages (T3), provided similar yield increases comparable to three applications of a commercial foliar fungicide at the same phenological stages (T9).

Our results show that the application of Trichoderma spp. onto seeds is an effective and least expensive method for the control of diseases severity of Septoria tritici blotch in crops compared to fungicides. Because Trichoderma is unable to survive on the leaf surfaces, especially under the summer weather conditions, and its population decreases rapidly when it is applied as an aerial inoculum (Perelló et al., 1997; Perelló et al., 2003), several researchers have chosen to incorporate the antagonist species by means of the seed coating technique (Perelló et al., 2006; Perelló et al., 2009; Dal Bello et al., 2002; Cordo et al., 2007; Stocco et al., 2009; Stocco et al., 2012). Regarding this technique, Perelló et al., (2008), established that Trichoderma spp. is effective only at the early stages of the diseases. However, our results, especially in the second year, demonstrated that the protection obtained with treatment T1 (only application by seed coating) was achieved until the dough growth stage (data non show). In addition, we have previously demonstrated that seed coating with $T$. harzianum is efficient to protect wheat against the pathogen of STB (Cordo et al., 2007, 2011, 2012) and that leaves of plants grown from these seeds did not contain the fungus. The protective efficacy of wheat seed coating is therefore due to an indirect effect, in which there is no contact between the pathogen and the biocontrol agent. Previous reports (Segarra et al., 2002; Cordo et al., 2007) have mentioned that $T$. harzianum strains induce biochemical plant defense responses similar to those published (Hoitink, 2006; Howell, 2006).

Segarra et al. (2003) demonstrated this biochemical proteolytic action, throughout one descripted leaf germinlike protease inhibitor. 


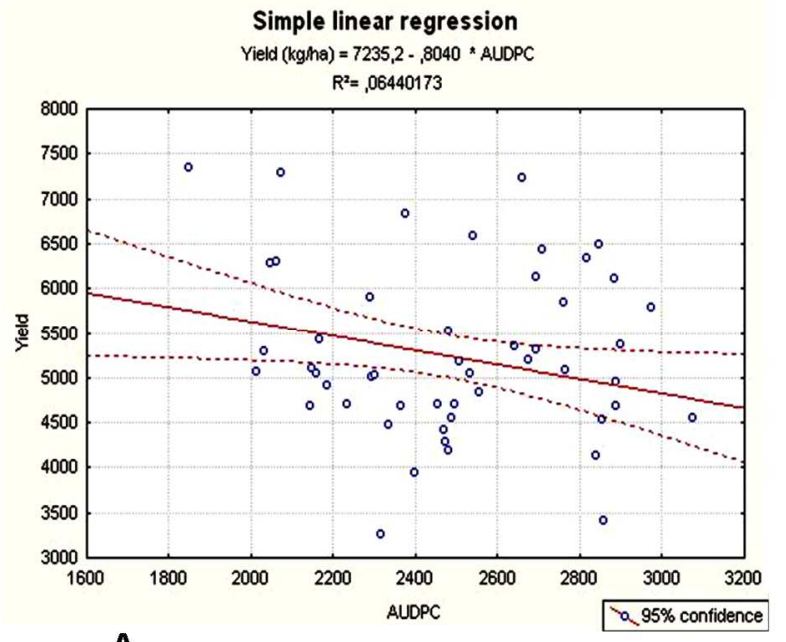

A

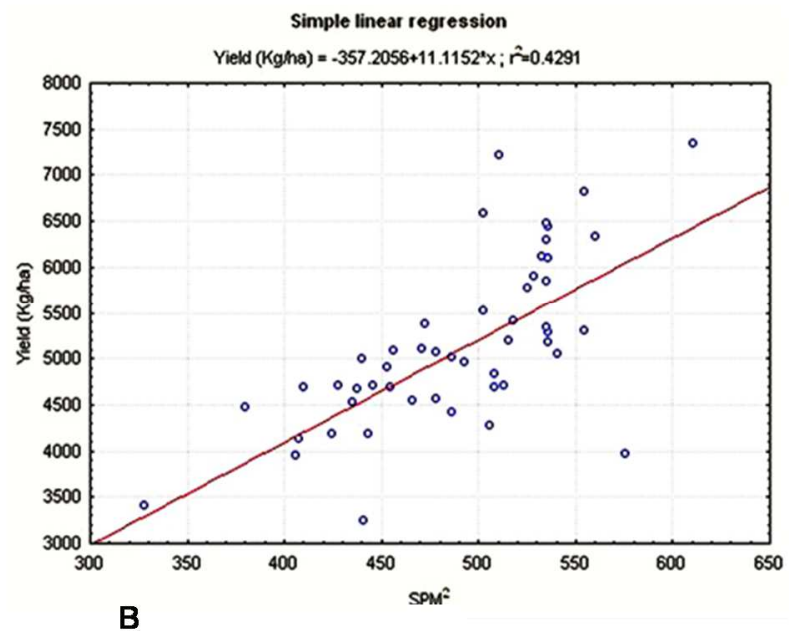

Simple linear regression

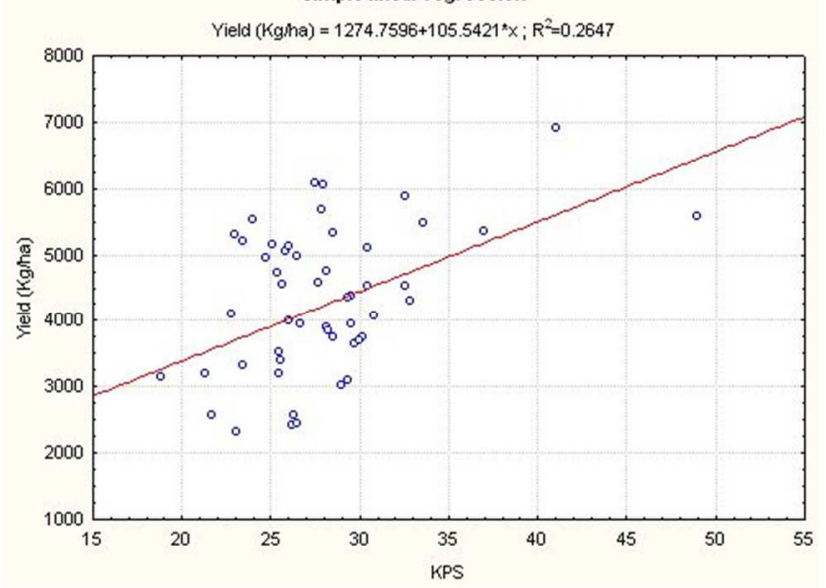

C

Figure 2. A Relationship between the Yield of the wheat cultivar Buck 55 CL2 and the AUDPC as consequence of STB diseases, 2010 year. B: Relationship between the Yield of the wheat cultivar Buck 55 CL2 and the number of spikes per square meter (SPM-2) as consequence of STB, 2010 year. C: Relationship between the Yield of the wheat cultivar Buck 55 CL2 and the number of kernels per spike (KPS) as consequence of STB, 2011 year. Strategies used: =T1, T2 and T3 biocontrol only, T4 to T6: biocontrol and fungicide combined; T7 to T10: fungicide only (negative control).

The decrease in the AUDPC with treatments T1 and T3 (seed coating and two aerial applications of $T$. harzianum at tillering and heading as reinforcement) as was demonstrated in Figure 1 in 2011 compared with 2010 could be explained by the predominance of rainfall and the decrease in radiation during the period, from the second node visible to heading stages, when yield and its components are defined The humidity and the cloudy days with low radiation as consequences of rainfall (October-November 2011) favoured the development of the disease (Cordo et al., 2017a; Cordo et al., 2017b) and protected $T$. harzianum spores from drying and becoming inactive. Moreover, treatments T2 and T4 in 2010 and T3 in 2011, with aerial applications of $T$. harzianum as reinforcement, favoured the decrease in the AUDPC. It would be due to an antagonistic mechanism based on the inhibition of conidia germination of $Z$. tritici by T.harzianum on wheat leaves (Perelló et al., 1997).

We hypothesized that the reduction of STB symptoms here observed can be attributed to a resistance that could be originated through elicitation triggered by the $T$. harzianum strains, such as the production of the proteolytic enzyme serine protease, that could active the mechanisms of wheat plant defense (Segarra et al., 2002). In a previous study, we demonstrated the restriction of STB progress in the susceptible cultivar PRO INTA Molinero pretreated with Trichoderma spp. isolates, before the infection with $Z$. tritici (Cordo et al., 2007). This protection can be transitory, but strongly potentiates the expression of defense-related proteins when plants are challenged by pathogens at sites distant from the location of the Trichoderma strain. 


\begin{tabular}{lcccccc}
\hline Treatments & \multicolumn{7}{c}{ Yield components } \\
\cline { 2 - 7 } & 2010 & 2011 & 2010 & 2011 & 2010 & 2011 \\
\cline { 2 - 7 } Positive Control & $440 \mathrm{a}^{*}$ & $360 \mathrm{a}$ & $37.3 \mathrm{ab}$ & $36.7 \mathrm{a}$ & $26.3 \mathrm{~b}$ & $22.5 \mathrm{a}$ \\
T1 & $510 \mathrm{bc}$ & $427.5 \mathrm{ab}$ & $38.9 \mathrm{a}$ & $37.7 \mathrm{a}$ & $27.4 \mathrm{ab}$ & $25.4 \mathrm{abc}$ \\
T2 & $530.5 \mathrm{c}$ & $468.9 \mathrm{~b}$ & $37.3 \mathrm{ab}$ & $38.5 \mathrm{a}$ & $28.2 \mathrm{ab}$ & $24.3 \mathrm{ab}$ \\
T3 & $512.5 \mathrm{bc}$ & $421 \mathrm{ab}$ & $37.3 \mathrm{ab}$ & $35.4 \mathrm{a}$ & $30.2 \mathrm{ab}$ & $28.9 \mathrm{abc}$ \\
T4 & $481.2 \mathrm{abc}$ & $449.1 \mathrm{ab}$ & $38.2 \mathrm{ab}$ & $37.3 \mathrm{a}$ & $29.3 \mathrm{ab}$ & $27.8 \mathrm{abc}$ \\
T5 & $459 \mathrm{ab}$ & $455.3 \mathrm{ab}$ & $37.9 \mathrm{ab}$ & $35 \mathrm{a}$ & $28.6 \mathrm{ab}$ & $27.8 \mathrm{abc}$ \\
T6 & $455.3 \mathrm{ab}$ & $439.1 \mathrm{ab}$ & $38.9 \mathrm{a}$ & $35.1 \mathrm{a}$ & $27.1 \mathrm{ab}$ & $28.5 \mathrm{abc}$ \\
T7 & $472.3 \mathrm{abc}$ & $369.9 \mathrm{ab}$ & $36.5 \mathrm{abc}$ & $40.9 \mathrm{a}$ & $28.3 \mathrm{ab}$ & $28.3 \mathrm{abc}$ \\
T8 & $506.3 \mathrm{bc}$ & $427.8 \mathrm{ab}$ & $35.6 \mathrm{bc}$ & $36.6 \mathrm{a}$ & $28.9 \mathrm{ab}$ & $34.1 \mathrm{bc}$ \\
T9 & $528.5 \mathrm{c}$ & $415.4 \mathrm{ab}$ & $36.8 \mathrm{abc}$ & $27.4 \mathrm{a}$ & $30.5 \mathrm{a}$ & $35.2 \mathrm{c}$ \\
T10 & $508.3 \mathrm{bc}$ & $397.7 \mathrm{ab}$ & $34.5 \mathrm{abc}$ & $35.1 \mathrm{a}$ & $29.4 \mathrm{ab}$ & $30.3 \mathrm{abc}$ \\
\hline
\end{tabular}

Table 4. Mean values for yield components with 10 treatments with Trichoderma harzianum/fungicide and the positive control for the wheat cultivar Buck 55 CL2 infected by Zymoseptoria tritici in field experiments performed in 2010 and 2011.

* Treatments with similar letters are not statistically different. Yield components: SPM ${ }^{2}$ spike per square meter; TKW thousand kernel weight; KPS kernel per spike.

In the present study, the higest values of $\mathrm{SPM}^{-2}$ in 2010 was the result of the higest number of plants per $\mathrm{m}^{-2}$ and the effect of humidity which conditioned tillering. Early protection (seed coating and early application at tillering) may affect the number of spikes, spikelet and flowers, as well as the weight of grains. There was a long period with decreased severity (from the beginning of hearing until close to anthesis) that defined a greater number of spikes per plant and therefore per $\mathrm{m}^{-2}$ resulting in an effect similar to that of a multiple application of fungicide at three growth stages.

Treatments with $T$. harzianum protected the plants until the start of flowering, which would favor greater accumulation of photosynthates and the consequent increase in biomass.

Our last results with the application of the antagonist alone were similar to those reported previously by other researchers (Simón et al., 2002; Couretot et al., 2011) using a mix of triazoles and strobilurins. These authors reported an increase in the number of $\mathrm{SPM}^{-2}$ and the number of grains per spike ${ }^{-1}$ as a consequence of an early and delayed protection from the effect of the fungicides on wheat. The good weather conditions during the critical period of 2011, favorable for the occurrence of diseases, could have been one of the reason because yield of the control was low as a consequence of the high infection, contrasting with the high values of yield and yield gain (\%) for treatments T1, T2, and T3 with $T$. harzianumapplication alone. These results would explain the association between KPS and yield in the Simple linear Regression model with an $\mathrm{R}^{2}=0.26$. The presence of $T$. harzianum on the leaves could stimulate the delay in the duration of the green leaf area increasing yield, similar that was observed with the application of a fungicide composed by strobilurins (Gooding et al., 2000).

In our study, the treatments with Trichodermaand/ or Trichoderma combined with fungicide or fungicide alone, generated a healthy green surface from which the grains take advantage of the soluble carbohydrates, that compensate the filling of them (Simón et al., 2002).

Finally, the low association (6\%) between yield and AUDPC might be possible explained not only for the amount of diseases but also for the environment and the genes present in the host and the pathogen. May be, the proper genes expression of the cultivar guided to a slow rate of the diseases with a reduction in yield (Shaner and Finney, 1977).

\section{CONCLUSIONS}

We concluded that for the first time in Argentina, was demonstrated the beneficial effect of seed coating and seed coating plus two aerial applications of $T$. harzianum for a tendence to increase( even though it was not significant) in grain yield in wheat and the improvement of the yield components. We recommend only one application on wheat seeds (seed coating) because, the protective effect was prolonged until the early dough stage of grain filling, resulting in a low cost of application during the growing cycle of the crop.

We propose that these two strains of $T$. harzianum should become part of the list of already existing microorganisms to be used to obtain biologicalproducts.

\section{ACKNOWLEDGMENTS}

This work received financial support from CIC Exp. 21571708/10. Resol. 1535/10, Exp. 2157-2316/11. Resol. 2410/12. We thank Ing. Agr. L. Gonzalez from Buck Semillas S.A. for providing seeds of the cultivar Buck 55CL2; we also thank the farm staff at Los Hornos Experimental Station, especially Ing. Agr. M. Pardi, for the management of the field experiments. 


\section{REFERENCES}

Altschul SF., T.L. Madden, A.A. Schaffer, J. Zhang, Z. Zhang, W. Miller \& D.J. Lipman. 1997 Gapped BLAST and PSI-BLAST: a new generation of protein database search programs". Nucleic Acids Research 25: 33893402.

Annone J., O. Calzolari, H. Polidoro \& C. Conta 1991 Efecto de la mancha de la hoja causada por Septoria tritici sobre el rendimiento. Informe 122; INTA EEA Pergamino, Pergamino, Argentina pp. 8.

Annone J., A. Calzolari, O. Polidoro \& H. Conta. 1993. Información adicional sobre el efecto de "mancha de la hoja" causada por Septoria tritici sobre los rendimientos. Informe 146 1993. INTA EEA Pergamino, Pergamino, Argentina, pp. 5.

Cordo, C, C. Monaco, C. Segarra, M. Simón, A. Mansilla, A. Perelló, N. Kripelz, D. Bayo \& R. Conde 2007.T. harzianum as elicitors of wheat plant defense response against Septoria tritici. Biocontrol Science and Technolog 17: 687-698.

Cordo, C., M. Simón, M. Stocco, G. Lampugnani, C. Abramoff, N. Kripelz, E. Alonso, E. Paredes, F. Navarrete \& C. Mónaco 2011. Combined treatment to reduce Septoria tritici in wheat and their impact on crop yield and its components. In Procceeding of the $8^{\circ}$ International Symposium of Mycosphaerella and Stagonospora diseases of wheat. (Duveiller E. Ed.) Mexico. D.F, p. 84.

Cordo C., M. Simon, M. Stocco, G. Lampugnani, C. Abramoff, N. Kripelz \& Monaco C., 2012 Aplicaciones de Trichoderma sp. y su efecto sobre el rendimiento y las curvas de progreso de la septoriosis del trigo. In: IVX Jornadas Fitosanitarias Argentinas. Potrero de Los Funes, San Luis, Argentina, p. 93.

Cordo C., C. Trofino, M. Stocco, C. Mónaco, N. Kripelz \& P.A. Balatti. 2017a. Cambio en la sensibilidad al fungicida tebuconazole en las poblaciones de Zymoseptoria tritici, patógeno de la septoriosis de la hoja del trigo. Cuarto Congreso Internacional Científico y tecnológico de la provincia de Bs. As. 1 de Septiembre de 2017, UNQUI, Ciudad de Quilmes, Buenos Aires, Argentina. 12pp.

Cordo, C., C. Trofino, M. Stocco, C. Mónaco \& N. Kripelz. 2017b. Tolerancia al fungicida tebuconazol en las poblaciones de Zymospetoria tritici, patógeno de la septoriosis del trigo. XXV Congreso de la Sociedad Chilena de Fitopatología, Chile. p 67.

Couretot, L., G. Ferraris \& R. Mousegne 2011. Experiencias en el control químico de enfermedades foliares de trigo y cebada en la zona Norte de la Pcia de Bs AS. Campaña 2010-11. INTA -Informe Estación Agropecuaria INTA Pergamino. Desarrollo Rural. p 7.

Dal Bello, G., C. Mónaco \& M. Simón 2002. Biological control of seedling blight of wheat caused by Fusarium graminearum with beneficial rhizosphere microorganisms. World Journal of Microbiology \& Biotechnology 18: 627-636.

Gooding, MJ., J.P.E. Dimmook, J. France \& S.A. Jones. 2000. Green leaf area decline of wheat flag leaves: the influence of fungicides and relationships with mean grain weight and grain yield. Annals of Applied Biology 136: 77-84.
Harman GE. 2001. Microbial tools to improve crop performance and profitability and to control plant diseases. In Eds. D.-D.S Tzeng \& J.W. Huang. Proceeding of International Symposium on Biologycal control of Plant Diseases for the new Century. Mode of action and Application Technology National Chung Hsing University Taichung City $\mathrm{p}$ 71-84.

Harman GE. 2006. Overview of mechanisms and uses of T. harzianum, Phytopathology 96: 190-194.

Harman, G., R. Howell, A. Viterbo, Y. Chet \& M. Lorito. 2004. Trichoderma species. Opportunistic, avirulent plant symbionts" Microbiology 2: 43-56.

Hermosa, R., B. Rubio, R. Cardoza, C. Nicolás, E. Monte \& S. Gutierrez. 2013. The contribution of Trichoderma to balancing the costs of plant growth and defense". International Microbiology 16: 69-80.

Hoitink, H., L. Madden \& E. Derrance. 2006. Systemeic resistance induced by Trichoderma spp.: interaction between the host, the pathogen, the biocontrol agent and soil organic matter quality Phytopathology 96: 186-189.

Howell CR. 2006. Understanding the mechanisms employed by Trichoderma virens to effect biological control of cotton diseases. Phytopathology 44: 395-417. Leroux, P., C. Albertini, A. Gautier, M. Grendt \& A.S. Walker. 2007. Mutations in the CYP gene correlated with hanges in sensitivity to sterol $14 \alpha$ - demethilation inhibitors in field isolates of Mycosphaerella graminicola. Pest management Science 63: 688-698.

Lorito, M., SL Woo \& SL.F. Scala. 2004 .Le biotecnologie utili alla difesa sostenibile delle piante: i funghi- Agroindustria.4: 37-41.

Lorito, M., S. Woo, G. Harman \& E. Monte. 2010. Translational research on Trichoderma from omics to the field. Annu. Rev. Phytopahol 48: 395-417.

Miyazaki, Y., N. Ohnishi, H. Takafumi \& T. Hiura. 2009. Genetics of dwarf bamboo do not die after one flowering event: evidence from genetic structure and flowering pattern. J Plant Res 122: 523-528.

Mónaco, C., G. Dal Bello, C. Rollán, L. Ronco, G. Lampugnani, N. Arteta, C. Abramoff, L. Ronco, A. Aprea, S. Larran \& M. Stocco. 2008. Biological control of Botrytis cinereal on tomato using naturally occurring fungal antagonists". Archives in Phytopathology and Plant Protection online.

Monte, E. 2001. Understanding Trichoderma: between biotechnology and microbial ecology". International Microbiology 4: 1-4.

Murray, MJ. \& W. Thompson. 1980. Rapid isolation for high molecular weight plant DNA. Nucleic Acid Research, 1980; 8:4321-4325.

Perelló A., C. Mónaco \& C. Cordo. 1997. Evaluation of Trichoderma harzianum and Gliocladium roseum in controlling leaf blotch of wheat (Septoria tritici) under in vitro and greenhouse conditions". Zeitschrift fur Pflanzenkrankheiten und Pflanzenschutz 104: 588-598.

Perelló, A., C. Mónaco, M. Sisterna \& G. Dal Bello. 2003. Biocontrol efficacy of Trichoderma isolates for Tan Spot of wheat in Argentina Crop Protection 22: 10991106.

Perelló, A, C. Mónaco, M. Moreno, C. Cordo \& M. Simón. 2006. The effect of Trichoderma harzianum and $T$. koningii on the control of tan spot (Pyrenophora tritici- 
repentis) and leaf blotch (Mycosphaerella graminicola) of wheat under field conditions in Argentina. Biocontrol Science and Technology 16: 803- 813.

Perelló, A., V. Moreno, C. Monaco, M. Simón \& C. Cordo. 2008. Biological control of Septoria triticiblotch on wheat by $T$. harzianum under field conditions in Argentina" BioControl 54: 113-122.

Perelló, A., V. Moreno, C. Mónaco, M. Simón \& C. Cordo. 2009. Biological control of Septoria tritici blotch of wheat by Trichoderma spp under field conditions in Argentina BioControl 54: 113-122.

Rodrigo S., B. Cuello Hormino, C. Gomes, 0. Santamaría \& R. Costa. 2015. Influence of fungicide treatments on diseases severity caused by Zymoseptoria tritici and on grain yield and quality parameters of bread making wheat under mediterranean conditions", European Journal of Plant Pathology 141: 99-109.

Segarra, C., C. Casalongue, M. Pinedo, C. Cordo \& D. Conde 2002. Changes in wheat leaf extracellular proteolytic activity after infection with Septoria tritici Journal of Phytopathology 150: 105-111.

Segarra C., C. Casalongue, M. Pinedo, V. Ronchi \& D. Conde. 2003. A Germin-like protein of wheat leaf apoplast inhibits serin proteases. Journal of Experimental Botany 54: 1335-1341.

Shaner, G. \& R. Finney. 1977. The effect of Nitrogen Fertilization on the expression of slow-mildewing resistance in Knox wheat. Phytopathology 67: 10511056.

Simón, M.R., M.C. Fleitas \& S. Schalamuk. 2013. Recent Advances on Integrated Foliar Disease Management with Special Emphasis in Argentina Wheat Production. Chapter 1 Fungicides - Showcases of Integrated Plant Disease Management from Around the World". INTECH: 34pp. http://dx.doi.org/10.5772/51950.
Simón, M.R., A.E. Perelló, C.A. Cordo \& H. Arriaga. 1996. Influencia de Septoria tritici Rob ex Dems. sobre el peso de mil granos y algunos parámetros de calidad en Triticum aestivum L. Ministerio de Agricultura, Pesca y Alimentación. Instituto Nacional de investigación y tecnología agropecuaria 11: 162-171.

Simón MR., A.E. Perelló, C.A. Cordo \& P. Struik. 2002. Influence of Septoria tritici on yield, yield components, and test weight of wheat under two nitrogen fertilization conditions Crop Science 42: 1974-1981.

Simon M.R., N. Castillo \& C. Cordo. 2016. New sources of resistance to Septoria Tritici Blotch in wheat seedlings". European Journal of Plant Pathology 146: 625-635.

Stocco M., C. Mónaco, N. Kripelz, C. Segarra, G. Lampugnani, C. Abramoff, G. Laporte, N. Arteta \& C. Cordo. 2009. Mecanismo de acción de T. harzianum para el biocontrol de la Septoriosis del trigo" In: XIII Jornadas Fitosanitarias Argentinas. Facultad de Agronomía y Agroindustrias. Universidad Nacional de Santiago del Estero, Termas de Río Hondo, Santiago del Estero p. 89 Stocco M., F. Consolo, C. Mónaco, N. Kripelz, G. Salerno \& C. Cordo. 2012 Control biológico de la mancha de la hoja del trigo con del género Trichoderma In: Cereales de invierno. Investigación científico-técnica, Eds. S. Stenglein, M. Moreno, M. Cogliatti, W. Rogers, M. Carmona, S. Lavado, Tandil Provincia de Buenos Aires: p. 193-205.

Thompson, W. \& R. Gaunt. 1986. The effect of speckled leaf blotch on apical development and yield in winter wheat in New Zealand, Annals of Botany 58: 39-48.

USDA-FAO.1975 The twelve orders of soil taxonomy, Available in http://www.fao.org/soils-portal/soilsurvey/soil-classification/usda-soil-taxonomy/en/.

Zadoks, C., Chang, C. \& C. Konzak. 1974. A decimal code for the growth stages of cereals Weed Res, 14: 415-421. 